\title{
KAJIAN PENGHEMATAN ENERGI LISTRIK UNTUK MEREDUKSI KONSUMSI BAHAN BAKAR SPESIFIK(SFC) GENERATOR SET CADANGAN PADA GEDUNG POLITEKNIK MUARA TEWEH
}

\author{
Juli Chandra Teruna \\ Politeknik Muara Teweh \\ julichandra19@gmail.com
}

\begin{abstract}
The electricity system in the Muara Teweh area is an electricity system that is not interconnected with the South and Central Kalimantan electricity system, where until 2015 the projected installed capacity has not been able to meet peak load needs, resulting in a deficit of $1 \mathrm{MW}$ which results in frequent rotating blackouts. This has an impact on customers, so to overcome this, Muara Teweh Polytechnic operates a generator set with a capacity of $140 \mathrm{kVA}$ as a backup power plant with diesel fuel. Based on the results of this study, the electrical power requirement at peak load in the Muara Teweh Polytechnic building is $94.168 \mathrm{~kW}$ with a specific fuel consumption of 28.16 liters in 1 (one) hour of operation. With good energy management, the Muara Teweh Polytechnic building can save up to 50\% of the peak load with a specific fuel consumption savings of 14.08 liters per hour.
\end{abstract}

Keywords-Generator set, installed capacity, peak load, Break Specific Fuel Consumption (BSFC) and Break Horse Power (BHP).

Intisari-Sistem kelistrikan di wilayah Muara Teweh merupakan sistem kelistrikan yang tidak terinterkoneksi dengan sistem kelistrikan Kalimantan Selatan dan Tengah, dimana sampai tahun 2015 kapasitas terpasang diproyeksikan belum dapat memenuhi kebutuhan beban puncak sehingga mengalami defisit 1 MW yang mengakibatkan sering terjadi pemadaman bergilir. Hal ini berimbas kepada pelanggan sehingga untuk mengatasinya Politeknik Muara Teweh mengoperasikan generator set berkapasitas 140 kVA sebagai pembangkit listrik cadangan dengan bahan bakar jenis solar. Berdasarkan hasil penelitian ini, kebutuhan daya listrik pada saat beban puncak di gedung Politeknik Muara Teweh sebesar 94,168 kW dengan konsumsi bahan bakar spesifik sebanyak 28,16 liter dalam 1 (satu) jam pengoperasiannya. Dengan manajemen energi yang baik, gedung Politeknik Muara Teweh dapat melakukan penghematan samapai 50\% dari beban puncak dengan penghematan konsumsi bahan bakar spesifik dalam pengoperasiannya sebesar 14,08 liter setiap jam.

Kata Kunci-Generator set, kapasitas terpasang, beban puncak, konsumsi bahan bakar spesifik/Break Specific Fuel Consumption (BSFC) dan Break Horse Power (BHP).

\section{PENDAHULUAN}

Kondisi kelistrikan di wilayah Kalimantan Selatan dan Tengah sampai tahun 2014 kapasitas terpasang mencapai 530,31 MW dengan beban puncak mencapai 505 MW. Kapasitas daya terpasang terbesar dari unit-unit pembangkit PLN di wilayah Kalimantan Selatan dan
Tengah adalah Pembangkit Listrik Tenaga Uap (PLTU) Asam-asam sebesar 4 x 65 MW. Dengan kondisi kelistrikan seperti ini, sistem kelistrikan di wilayah Kalimantan Selatan dan Tengah harus memiliki cadangan daya listrik minimal sebesar kapasitas terbesar yaitu sebesar $65 \mathrm{MW}$ [1].

Sistem kelistrikan di wilayah Muara Teweh dan sekitarnya merupakan salah satu sistem yang terisolasi dari sistem kelistrikan Kalimantan Selatan dan Tengah, dimana sistem pembangkitan listriknya mengandalkan unit-unit pembangkit tenaga diesel (PLTD). Kapasitas pembangkitan listrik tenaga diesel di Muara Teweh sebesar 6,99 MW yang terdiri dari 7 (tujuh) unit pembangkit dengan kapasitas sebesar 5,99 MW dan sisanya dari sewa mesin pembangkit dari pihak ketiga sebesar 1 MW. Berdasarkan Rencana Penyediaan Tenaga Listrik Kalselteng [2], prakiraan beban puncak di wilayah Muara Teweh pada tahun 2015 diproyeksikan mencapai 7,91 MW sehingga terjadi defisit daya sekitar $1 \mathrm{MW}$, hal ini akan mengakibatkan pemadaman listrik bergilir di wilayah Muara Teweh.

Melihat kondisi sistem kelistrikan di atas, pemenuhan kebutuhan utama energi listrik pada gedung Politeknik Muara Teweh tidak dapat mengandalkan sepenuhnya dari pasokan dari PLN Muara Teweh, sehingga untuk pemenuhan kebutuhan apabila pasokan dari PLN terputus atau mengalami pemadaman, gedung Politeknik Muara Teweh menggunakan sumber pembangkit listrik cadangan berupa generator set dengan mesin diesel berbahan bakar solar dengan kapasitas pembangkitan daya sebesar $140 \mathrm{kVA}$. Penelitian ini dilakukan untuk mengetahui kebutuhan konsumsi bahan bakar solar dalam pembangkitan daya listrik dengan generator set pada gedung Politeknik Muara Teweh sehingga dapat dipergunakan sebagai dasar perhitungan biaya operasional pembangkitan generator set pada Gedung Politeknik Muara Teweh.

\section{LANDASAN TEORI}

\subsection{Generator Set}

Generator arus bolak-balik (AC) atau alternator adalah suatu peralatan yang berfungsi untuk mengkonversikan energi mekanik menjadi energi listrik melalui proses induksi elektromagnetik.

Prinsip kerja generator sinkron berdasarkan induksi elektromagnetis. Rotor diputar oleh penggerak mula (prime mover) sehingga kutub-kutub yang ada pada 
rotor akan berputar. Kumparan medan yang terdapat pada rotor dihubungkan dengan sumber eksitasi yang akan disuplai oleh arus searah sehingga menimbulkan fluks yang besarnya tetap terhadap waktu [3].

\subsection{Daya Listrik}

Daya dalam sistem pembangkitan listrik bolak balik (AC) terdiri dari daya aktif (P) dengan satuan watt, daya reaktif (Q) dengan satuan VAR dan daya kompleks (S) dengan satuan VA, dimana hubungan ketiga daya tersebut direpresentasikan melalui gambar segitiga daya.

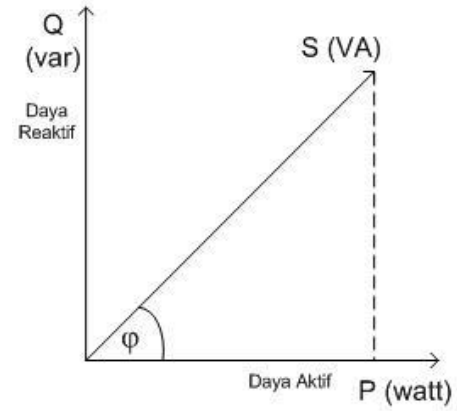

Gambar 1. Segitiga Daya

Berdasarkan gambar segitiga daya di atas, generator menghasilkan daya aktif sebesar P, daya reaktif sebesar Q dan totalnya secara vektor disebut daya kompleks S. Daya aktif $(\mathrm{P})$ dalam satuan watt adalah daya yang digunakan untuk energi kerja sebenarnya. Daya ini yang dikonversikan menjadi energi tenaga mekanik, cahaya atau panas. Daya reaktif (Q) dalam satuan VAR adalah daya yang digunakan untuk pembangkitan fluks magnetik atau medan magnet. Peralatan-peralatan listrik yang memerlukan daya reaktif adalah motor listrik atau dinamo, trafo, ballast lampu yang konvensional dan peralatan listrik lain yang menggunakan proses induksi listrik lilitan untuk operasinya, sedangkan daya nyata $(\mathrm{S})$ dengan satuan VA adalah total perkalian antara arus dan tegangan pada suatu jaringan listrik atau penjumlahan dengan metode trigonometri dari daya aktif dan reaktif dalam segitiga daya.

Gambar segitiga daya tersebut di atas juga merepresentasikan nilai faktor daya atau $\cos \varphi$ dalam hubungannya dengan daya. Hubungan 4 variabel secara matematis adalah sebagai berikut [4]:

$$
\begin{aligned}
& \text { Daya aktif }=\mathrm{P}=\mathrm{VI} \cos \varphi \\
& \text { Daya reaktif }=\mathrm{Q}=\mathrm{VI} \sin \varphi \\
& \text { Daya kompleks }=\mathrm{S}=\sqrt{ }\left(\mathrm{P}^{2}+\mathrm{Q}^{2}\right)=\mathrm{VI} \\
& \text { Faktor daya }(\cos \varphi)=\mathrm{P} / \mathrm{S}
\end{aligned}
$$

Sedangkan untuk daya aktif yang dibangkitkan generator 3 fasa adalah sebagai berikut [5] :

$$
P=\sqrt{ } 3 V_{L} I_{L} \cos \varphi
$$

\subsection{Mesin Diesel}

Mesin (engine) sebagai perangkat pemutar sedangkan genarator atau alternator sebagai perangkat pembangkit listrik. Engine dapat berupa perangkat mesin disel berbahan bakar solar, mesin berbahan bakar bensin, mesin gas, maupun mesin turbin ada bermacam-macam mesin sesuai dengan kebutuhan.
Mesin diesel termasuk mesin dengan pembakaran dalam dimana energi dimanfaatkan adalah energi termalnya (energi panas). Untuk membangkitkan listrik, sebuah mesin diesel dihubungkan dengan generator dalam satu poros. Penggerak mula atau prime mover merupakan peralatan yang berfungsi menghasilkan energi mekanis yang diperlukan untuk memutar rotor generator. Pada mesin diesel/diesel engine terjadi penyalaan sendiri, karena proses kerjanya berdasarkan udara murni yang dimampatkan di dalam silinder pada tekanan yang tinggi ( $\pm 30 \mathrm{~atm}$ ), sehingga temperatur di dalam silinder naik. Dan pada saat itu bahan bakar disemprotkan dalam silinder yang bersuhu dan bertekanan tinggi melebihi titik nyala bahan bakar sehingga bahan bakar yang diinjeksikan akan terbakar secara otomatis. Penambahan panas atau energi senantiasa dilakukan pada tekanan yang konstan.

Dalam sistem pembangkitan listrik tenaga diesel, daya dari mesin diesel (Break Horse Power, BHP) merupakan daya masukan (input) mekanik untuk memutar generator set sehingga menghasilkan daya keluaran (output) listrik. Perbandingan antara daya keluaran (POut) dan daya masukan (Pin) akan menunjukan efisiensi ( $\eta$ ) kerja mesin generator set. Nilai efisensi mesin diesel dan generator biasanya sudah tertera pada name plate atau katalog produk mesin atau dapat dihitung dengan persamaan berikut :

$$
\eta=\mathrm{P}_{\text {Out }} /\left(\mathrm{P}_{\text {In }}(\mathrm{BHP})\right) \times 100 \%
$$

Membuat estimasi konsumsi bahan bakar berdasarkan pada kalkulasi total daya beban dari penggunaan peralatan listrik. Berdasarkan perhitungan ini dapat dilihat pemakaian bahan bakar pada generator yang digerakan motor bensin dibanding dengan yang digerakan motor diesel. Pada beberapa produk, konsumsi bahan bakar spesifik (BSFC) sudah dapat diketahui melalui katalog maupun buku manual produk. Estimasi konsumsi bahan bakar motor diesel dapat dihitung dengan persamaan berikut [6] :

$$
\mathrm{S}=\mathrm{k} \times \mathrm{P} \times \mathrm{t}
$$

Dengan

$\mathrm{S}=$ Konsumsi solar (liter)

$\mathrm{k}=0,2$ (Faktor ketetapan konsumsi solar liter per $\mathrm{kW}$ per jam)

$\mathrm{P}=$ Daya generator $(\mathrm{kW})$

$\mathrm{t} \quad$ = Waktu (jam)

Konsumsi bahan bakar spesifik atau break specific fuel consumption (BSFC) dari suatu generator berdasarkan pada jumlah pemakaian bahan bakar yang dibagi dengan daya output motor bergerak. Dalam perhitungan estimasi bahan bakar pada mesin diesel untuk generator, daya output motor bergerak dianggap sama dengan daya yang dikonsumsi (daya beban) dan harga rata-rata konsumsi bahan bakar spesifik dihitung dengan persamaan berikut [7]:

$$
B S F C=\frac{\tilde{m}}{B H P}
$$


dengan

BSFC $=$ Break Specific Fuel Consumption $(\mathrm{g} / \mathrm{kWh})$

$\dot{m} \quad=$ Konsumsi bahan bakar per waktu $(\mathrm{kg} / \mathrm{s})$

$\mathrm{BHP}=$ Break Horse Power $(\mathrm{kW})$

Konsumsi bahan bahan spesifik secara umum dapat diketahui sebagai berikut [6] :

a. Otto (gasoline) engine : $273-227 \mathrm{~g} / \mathrm{kWh}$, dengan nilai rata-rata $250 \mathrm{~g} / \mathrm{kWh}$

b. Diesel engine : 209 - $178 \mathrm{~g} / \mathrm{kWh}$, dengan nilai rata-rata $194 \mathrm{~g} / \mathrm{kWh}$.

Estimasi konsumsi bahan bakar spesifik motor diesel dapat dihitung dengan persamaan [7] :

$$
\mathrm{S}_{\text {Spesifik }}=\mathrm{BSFC} \times \mathrm{BHP} \times \mathrm{t}
$$

\section{Dengan}

SSpesifik $=$ Konsumsi solar $($ gram $)$

BSFC = Konsumsi bahan bakar spesifik (gram/kWh)

BHP = Beban keluaran $(\mathrm{kW})$

$$
\mathrm{t}=\text { Waktu (hour) }
$$

Sedangkan berat jenis suatu bahan bakar bergantung pada temperatur dan kandungannya, dan secara umum dapat diambil harga rata-rata dari berat jenis bahan bakar adalah sebagai berikut [6]:

a. Bensin $0,745 \mathrm{~kg} / \mathrm{L}$

b. Solar $0,832 \mathrm{~kg} / \mathrm{L}$

Secara umum harga rata-rata konsumsi bahan bakar spesifik adalah dapat dihitung dengan persamaan [6] :

$$
\mathrm{S}_{\text {(rata-rata) }}=\mathrm{S}_{\text {Spesifik }} /(\text { berat jenis bahan bakar })
$$

\section{METODE PENELITIAN}

Penelitian tentang estimasi konsumsi bahan bakar generator set dalam pembangkitan daya listrik untuk memenuhi kebutuhan energi listrik pada gedung Politeknik Muara Teweh ini merupakan penelitian kuantitatif deskriptif, dimana data-data yang akan dipergunakan dalam penelitian ini adalah besarnya daya yang dibangkitkan oleh generator set dan besarnya beban pemakaian daya listrik yang dipakai oleh gedung Politeknik Muara Teweh.

Variabel-variabel dalam yang dipergunakan penelitian ini adalah daya mekanik yang dihasilkan mesin diesel dan daya listrik yang dibangkitkan oleh generator set serta daya listrik yang dibutuhkan oleh gedung Politeknik Muara Teweh.

Sumber data yang dipergunakan dalam penelitian ini adalah data-data hasil pengukuran dari daya listrik yang dibangkitkan oleh generator set maupun data teknis dari mesin diesel dan perhitungan konsumsi daya listrik saat beban puncak pada gedung Politeknik Muara Teweh.

Analisis dari penelitian ini dilakukan dengan menghitung data-data berupa daya listrik yang terbangkit dari generator set dengan kebutuhan daya listrik pada gedung Politeknik Muara Teweh, sehingga dapat diketahui daya mekanik yang dikeluarkan mesin diesel sehingga dapat dihitung konsumsi bahan bakar spesifik dan pada akhirnya dapat memproyeksikan kebutuhan konsumsi bahan bakar solar dalam pembangkitan daya listrik dari generator set pada gedung Politeknik Muara Teweh. Data daya listrik yang terbangkit dapat diketahui dari name plate yang tertera pada generator set dan juga daya yang tertera pada layar display kontrol pada saat generator set dioperasikan. Sedangkan data-data kebutuhan daya listrik dari diperoleh dari pengukuran penggunaan peralatan-peralatan listrik yang dipergunakan terutama saat beban puncak pada gedung Politeknik Muara Teweh.

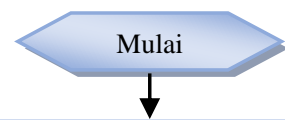

Mengumpulkan data-data teknis dari generator untuk mengetahui kapasitas pembangkitan daya listrik dari generator dan data-data teknis dari mesin diesel

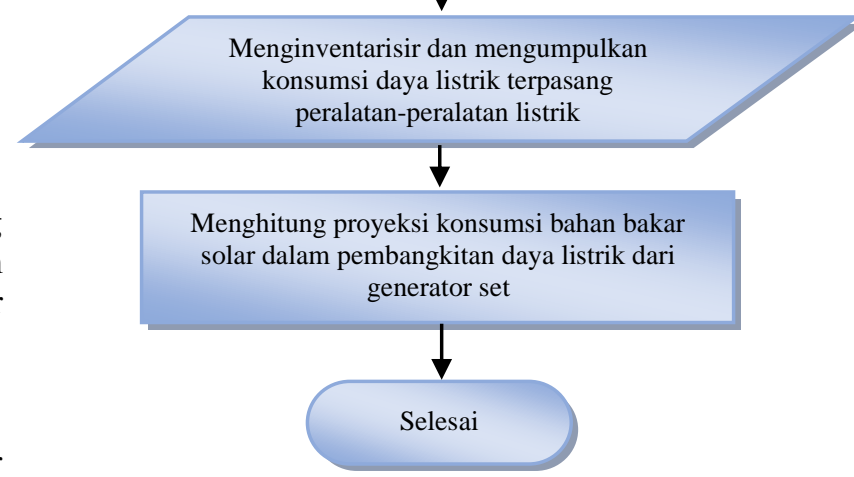

Gambar 2. Diagram Alir Penelitian

\section{HASIL DAN PEMBAHASAN}

Setelah melakukan observasi dan pengukuran datadata di lapangan dapat diketahui data spesifikasi teknis dari generator set, mesin diesel serta inventarisir peralatan-peralatan dan konsumsi daya listrik yang dipergunakan di gedung Politeknik Muara Teweh. Berdasarkan data-data yang telah dikumpulkan ini maka dapat dihitung dan diketahui proyeksi konsumsi bahan bakar solar dalam pembangkitan generator set untuk memenuhi kebutuhan daya dari peralatan-peralatan yang digunakan pada gedung Politeknik Muara Teweh.

4.1 Data Teknis Generator Set

Generator set yang dipergunakan sebagai pembangit listrik cadangan pada gedung Politeknik Muara Teweh adalah generator sinkron 3 fasa dengan merk Rexford tipe RF274E14 dengan kapasitas daya terbangkit sebesar $140 \mathrm{kVA}$

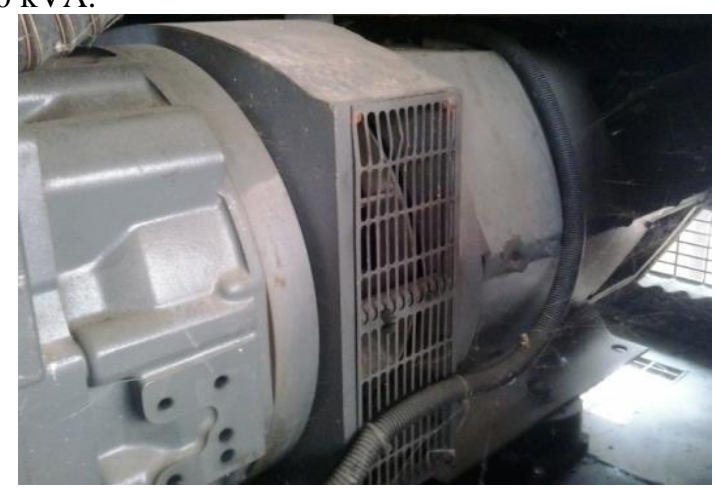

Gambar 3. Generator Sinkron 3 fasa merk Rexford

Adapun data teknis dari generator set tersebut seperti tabel berikut. 
Tabel 1. Data Teknis Generator Set 3 Fasa merk Rexford

\begin{tabular}{|c|l|l|}
\hline No. & \multicolumn{1}{|c|}{ Data Teknis } & \multicolumn{1}{|c|}{ Kuantitas } \\
\hline 1. & Daya Nyata $(\mathrm{S})$ & $140 \mathrm{kVA}$ \\
\hline 2. & Tegangan $(\mathrm{V})$ & $400 \mathrm{Volt}$ \\
\hline 3. & Arus $(\mathrm{I})$ & $202 \mathrm{Amper}$ \\
\hline 4. & Faktor Daya $(\cos \varphi)$ & 0,8 \\
\hline 5. & Frekuensi $(f)$ & $50 \mathrm{~Hz}$ \\
\hline 6. & Efisiensi $(\eta)$ & 0,88 \\
\hline 7. & Putaran $(n)$ & $1500 \mathrm{rpm}$ \\
\hline
\end{tabular}

Berdasarkan data-data teknis generator set 3 fasa di atas dapat dihitung kapasitas pembangkitan daya aktif dari generator set tersebut. Sesuai persamaan dari segitiga daya diketahui hubungan daya nyata $(\mathrm{S})$, daya aktif $(\mathrm{P})$ dan faktor daya $(\cos \varphi)$ yaitu $\cos \varphi=\frac{P}{S}$ sehingga daya aktif dapat dihitung dengan persamaan $P=S \times \cos \varphi$.

Daya aktif $(\mathrm{P})$ yang dibangkitkan oleh generator set merk Rexford sebesar (1) :

$$
\begin{aligned}
\boldsymbol{P} & =\boldsymbol{S} \cdot \cos \varphi \\
& =140000 \mathrm{VA} \times 0,8 \\
& =112000 \mathrm{Watt} \\
& =112 \mathrm{~kW}
\end{aligned}
$$

Daya aktif (P) yang dibangkitkan oleh generator set 3 fasa merk Rexford juga dapat dihitung (5) :

$$
\begin{aligned}
\boldsymbol{P} & =\sqrt{3} \boldsymbol{V}_{I_{L}} \boldsymbol{I}_{\boldsymbol{L}} \cos \boldsymbol{\varphi} \\
& =\sqrt{3} \cdot 400 \times 202 \times 0,8 \\
& =111959,7642 \text { Watt } \\
& \approx 112 \mathrm{~kW}
\end{aligned}
$$

Selanjutnya daya reaktif (Q) yang dibangkitkan oleh generator set merk Rexford dengan persamaan (3) berikut:

$$
\begin{aligned}
\boldsymbol{S} & =\sqrt{\boldsymbol{P}^{2}+\boldsymbol{Q}^{2}} \text { atau } \\
\boldsymbol{Q} & =\sqrt{\boldsymbol{S}^{2}-\boldsymbol{P}^{2}} \\
& =\sqrt{(140000)^{2}-(112000)^{2}} \\
& =\sqrt{7056000000} \text { VAR } \\
& =84000 \text { VAR }=\mathbf{8 4} \mathbf{k V A}
\end{aligned}
$$

\begin{tabular}{|c|c|c|c|c|c|}
\hline \multirow{2}{*}{$\begin{array}{l}\mathbf{N} \\
\mathbf{o}\end{array}$} & \multirow{2}{*}{$\begin{array}{l}\text { Nama } \\
\text { Gedung }\end{array}$} & \multicolumn{4}{|c|}{$\begin{array}{c}\text { Karakteristik Beban Daya Listrik } \\
(\mathrm{kW})\end{array}$} \\
\hline & & Lampu & $\mathbf{A C}$ & $\begin{array}{l}\text { PC dan } \\
\text { Laptop }\end{array}$ & $\begin{array}{l}\text { Lain- } \\
\text { lain }\end{array}$ \\
\hline 2. & $\begin{array}{l}\text { Lantai } 2 \\
\text { Direktorat }\end{array}$ & 0,720 & 4,103 & 51,292 & 1,017 \\
\hline 3. & $\begin{array}{l}\text { Lantai } 1 \\
\text { Perkuliahan }\end{array}$ & 0,972 & 3,357 & 3,084 & 1,714 \\
\hline 4. & $\begin{array}{l}\text { Lantai } 2 \\
\text { Perkuliahan }\end{array}$ & 1,080 & 3,357 & 3,932 & 3,456 \\
\hline \multicolumn{2}{|r|}{ Tot a l } & 3,762 & 15,29 & 67,156 & $\mathbf{7 , 9 5 7}$ \\
\hline \multicolumn{2}{|c|}{$\begin{array}{c}\text { Total konsumsi } \\
\text { dava }\end{array}$} & \multicolumn{4}{|c|}{$94,168 \mathrm{~kW}$} \\
\hline
\end{tabular}

\subsection{Kebutuhan Daya Listrik}

Karakteristik beban daya listrik pada gedung Politeknik Muara Teweh terdiri dari beban daya listrik untuk penerangan, pengkondisi suhu ruangan (AC), peralatan elektronik (komputer dan laptop), peralatan laboratorium serta perlatan pendukung akademik lainnya, dimana pengoperasian peralatan-peralatan listrik tersebut dari pukul 8 pagi samapai pukul 14 siang (rata-rata 6 jam per hari).

Tabel 2. Karakteristik Konsumsi Daya (kW) Peralatan Listrik pada Gedung Politeknik Muara Teweh

\begin{tabular}{|c|c|c|c|c|c|}
\hline \multirow{2}{*}{$\begin{array}{c}\text { N } \\
\text { o }\end{array}$} & \multirow{2}{*}{$\begin{array}{c}\text { Nama } \\
\text { Gedung }\end{array}$} & \multicolumn{4}{|c|}{ Karakteristik Beban Daya Listrik } \\
\cline { 3 - 6 } & Lampu & AC & $\begin{array}{c}\text { PC dan } \\
\text { Laptop }\end{array}$ & $\begin{array}{c}\text { Lain- } \\
\text { lain }\end{array}$ \\
\hline 1. & $\begin{array}{l}\text { Lantai 1 } \\
\text { Direktorat }\end{array}$ & 0,990 & 4,476 & 8,848 & 1,770 \\
\hline
\end{tabular}

Berdasarkan karakteristik penggunaan beban peralatan-peralatan listrik di gedung Politeknik Muara Teweh di atas, dapat diketahui bahwa pemakaian komputer dan laptop terutama di Laboratorium Komputer 1 dan 2 serta Laboratorium Multimedia mengkonsumsi daya listrik terbesar yaitu sebesar $71 \%$ dari total penggunaan daya listrik. Berdasarkan rekapitulasi konsumsi daya listrik pada Tabel 4.6. di atas, maka diketahui bahwa beban puncak penggunaan daya listrik (P) untuk peralatan-peralatan listrik di gedung Politeknik Muara Teweh dari pukul 8 pagi sampai dengan pukul 14 siang adalah sebesar $94,168 \mathrm{~kW}$.

Faktor daya $(\cos \varphi)$ dari penyaluran daya listrik baik dari PT. PLN maupun dari generator set (cadangan) adalah sebesar 0,8 sehingga dengan menggunakan teorema segitiga daya, dapat dihitung daya kompleks (S) dari konsumsi daya aktif (P) dari peralatan-peralatan listrik yang dipergunakan pada gedung Politeknik Muara Teweh yaitu sebesar (4) :

$$
\begin{aligned}
\cos \varphi & =\frac{P}{S} \text { sehingga }_{a} \\
S & =\frac{P}{\cos \varphi} \\
& =\frac{94,168 \mathrm{~kW}}{0,8} \\
& =117,71 \mathrm{kVA}
\end{aligned}
$$

Berdasarkan karakteristik peralatan-peralatan listrik yang digunakan, dapat diasumsikan peralatan-peralatan tersebut juga menyerap daya reaktif sebesar (3) :

$$
\begin{aligned}
\boldsymbol{S} & =\sqrt{\boldsymbol{P}^{2}+\boldsymbol{Q}^{2}} \text { atau } \\
\boldsymbol{Q} & =\sqrt{\boldsymbol{S}^{2}-\boldsymbol{P}^{2}} \\
& =\sqrt{(117710)^{2}-(94168)^{2}} \\
& =\sqrt{4988031876} \text { VAR } \\
& =70626 \text { VAR }=70,626 \mathrm{kVAR}
\end{aligned}
$$

Jika pengelola Politeknik menerapkan sistem manajemen energi yang baik seperti mengontrol pengkondisi udara pada ruangan-ruangan yang tidak dipergunakan, mengkondisikan mode screen saver pada PC dan laptop yang tidak dipergunakan terus-menerus, memanfaatkan penerangan alami pada siang hari serta melakukan penghematan pada semua peralatan listrik lainnya maka dapat diasumsikan konsumsi daya listrik akan berkurang sehingga beban puncak juga akan berkurang seperti yang terjadi pada di bawah ini. 
Tabel 3. Asumsi Penghematan Konsumsi Daya Listrik (kW) pada Gedung Politeknik Muara Teweh

\begin{tabular}{|c|c|c|c|c|c|c|}
\hline \multirow{2}{*}{$\begin{array}{l}\mathbf{N} \\
\mathbf{o}\end{array}$} & \multirow{2}{*}{$\begin{array}{l}\text { Nama } \\
\text { Gedung }\end{array}$} & \multicolumn{5}{|c|}{$\begin{array}{c}\text { Asumsi Pengematan Daya Listrik } \\
(\mathrm{kW}) \text { dari Beban Puncak }\end{array}$} \\
\hline & & $\begin{array}{l}10 \\
\%\end{array}$ & $\begin{array}{l}20 \\
\%\end{array}$ & $\begin{array}{l}30 \\
\%\end{array}$ & $\begin{array}{l}40 \\
\%\end{array}$ & $\begin{array}{l}\mathbf{5 0} \\
\%\end{array}$ \\
\hline 1 & $\begin{array}{l}\text { Lantai } 1 \\
\text { Direktorat }\end{array}$ & 14,5 & 12,9 & 11,3 & 9,7 & 8,0 \\
\hline 2 & $\begin{array}{l}\text { Lantai } 2 \\
\text { Direktorat }\end{array}$ & 51,4 & 45,7 & 40,0 & 34,3 & 28,5 \\
\hline 3 & $\begin{array}{l}\text { Lantai } 1 \\
\text { Perkuliahan }\end{array}$ & 8,2 & 7,3 & 6,4 & 5,5 & 4,5 \\
\hline 4 & $\begin{array}{l}\text { Lantai } 2 \\
\text { Perkuliahan }\end{array}$ & 10,6 & 9,4 & 8,3 & 7,1 & 5,9 \\
\hline \multicolumn{2}{|c|}{$\begin{array}{l}\text { Total konsumsi } \\
\text { daya }(\mathrm{kW})\end{array}$} & 84,7 & 75,3 & 66,0 & 56,6 & 46,9 \\
\hline
\end{tabular}

Berdasarkan rekapitulasi asumsi penghematan daya listrik pada Tabel 4.7. di atas, maka diketahui bahwa beban puncak penggunaan daya listrik untuk peralatan-peralatan listrik di gedung Politeknik Muara Teweh dari pukul 8 pagi sampai dengan pukul 14 siang dapat diasumsikan sebesar 46,9 kW sampai dengan $84,7 \mathbf{k W}$

4.3 Data Teknis Mesin Diesel

Penggerak utama (prime mover) dari generator set adalah mesin diesel dengan merk Deutz tipe BF 6M 1013E bermesin turbo.

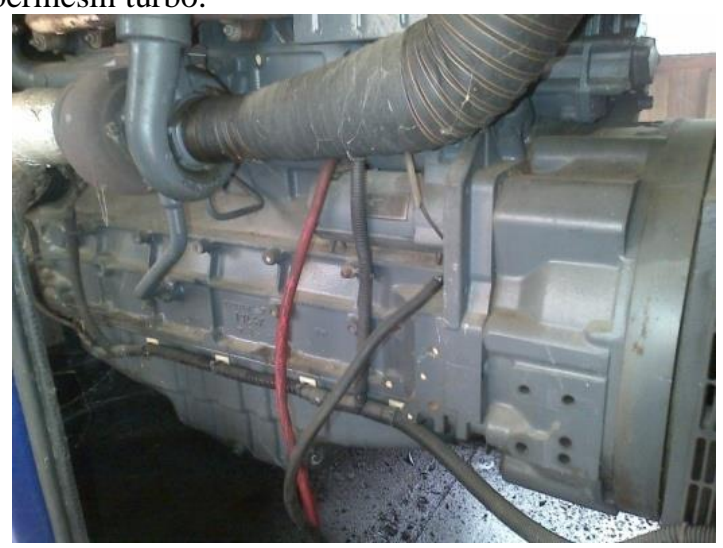

Gambar 4. Mesin diesel merk Deutz tipe BF 6M 1013-E

Adapun data teknis dari mesin diesel tersebut seperti tabel berikut.

Tabel 4. Data Teknis Mesin Diesel merk Duetz BF 6M 1013-E

\begin{tabular}{|c|l|l|}
\hline No. & \multicolumn{1}{|c|}{ Data Teknis } & \multicolumn{1}{|c|}{ Kuantitas } \\
\hline 1. & Daya & $128 \mathrm{~kW}$ \\
\hline 2. & Putaran $(n)$ & $1500 \mathrm{rpm}$ \\
\hline 3. & Efisiensi $(\eta)$ & 0,95 \\
\hline 4. & Frekuensi $(f)$ & $50 \mathrm{~Hz}$ \\
\hline 5. & Jumlah silinder & $6(\mathrm{enam})$ \\
\hline 6. & Specific Fuel Consumption & $\begin{array}{l}208-212 \\
\mathrm{~g} / \mathrm{kWh}\end{array}$ \\
\hline 7. & Sistem pendingin & $\begin{array}{l}\text { External } \\
\text { Cooled }\end{array}$ \\
\hline
\end{tabular}

4.4 Estimasi Konsumsi Bahan Bakar

Berdasarkan rekapitulasi kebutuhan beban daya listrik gedung Politeknik Muara Teweh pada saat beban puncak adalah sebesar 94,168 kW, maka daya masukan $P_{I n}$ (BHP) dapat dihitung dengan persamaan (6) :

$$
\begin{aligned}
\eta= & \frac{P_{\text {Out }}}{P_{\text {In }}(B H P)} \times 100 \% \\
P_{I n}(B H P) & =\frac{P_{\text {Out }}}{\eta}=\frac{P_{\text {Out }}}{\left(\eta_{\text {mek }} \times \eta_{g}\right)} \\
& =\frac{94,168 \mathrm{~kW}}{(0,95 \times 0,88)} \\
& =\mathbf{1 1 2 , 6 4 k W}
\end{aligned}
$$

Sedangkan estimasi konsumsi bahan bakar spesifik dari mesin diesel untuk menggerakan generator pada saat beban puncak selama 1 (satu) jam dapat dihitung dengan persamaan (7) :

$$
\begin{aligned}
S_{\text {Spesifik }} & =S F C \times B H P \times t \\
& =208 \frac{\mathrm{g}}{\mathrm{kWh}} \times 112,64 \mathrm{~kW} \\
& =23429,12 \mathrm{~g}=23,43 \mathrm{~kg}
\end{aligned}
$$

sehingga secara umum harga rata-rata konsumsi bahan bakar spesifik adalah dapat dihitung dengan persamaan (10) :

$$
\begin{aligned}
S_{\text {rerata }} & =\frac{S_{\text {Spesifik }}}{\text { berat jenis bahan bakar solar }} \\
& =\frac{23,43 \mathrm{~kg}}{0,832 \mathrm{~kg} / \mathrm{l}}=\mathbf{2 8 , 1 6 l}
\end{aligned}
$$

Jadi estimasi harga rata-rata konsumsi bahan bakar spesifik mesin diesel untuk menggerakan generator set selama 1 (satu) jam adalah sebanyak 28,16 liter. Berdasarkan rekapitulasi asumsi penghematan konsumsi daya listrik peralatan listrik (Tabel 3) yang ada pada gedung Politeknik Muara Teweh, estimasi konsumsi bahan bakar spesifik dari mesin diesel untuk menggerakan generator dengan asumsi pengehematan $10 \%$ dari beban puncak selama 1 (satu) jam dapat dihitung dengan persamaan (6) :

$$
\begin{aligned}
P_{\text {In }}(B H P) & =\frac{P_{\text {Out }}}{\eta}=\frac{P_{\text {Out }}}{\left(\eta_{\text {mek }} \times \eta_{g}\right)} \\
& =\frac{84,7 \mathrm{~kW}}{(0,95 \times 0,88)}=101,32 \mathrm{~kW}
\end{aligned}
$$

Sedangkan estimasi konsumsi bahan bakar spesifik dari mesin diesel untuk menggerakan generator pada saat beban puncak selama 1 (satu) jam dapat dihitung dengan persamaan (7) :

$$
\begin{aligned}
S_{\text {Spesifik }} & =S F C \times B H P \times t \\
& =208 \mathrm{~g} / \mathrm{kWh} \times \\
& 101,32 \mathrm{~kW} \times 1 \mathrm{~h} \\
& =21074,56 \mathrm{~g}=21,08 \mathrm{~kg}
\end{aligned}
$$

sehingga secara umum harga rata-rata konsumsi bahan bakar spesifik adalah dapat dihitung dengan persamaan (10) :

$$
\begin{aligned}
S_{\text {rata-rata }} & =\frac{S_{\text {Spesifik }}}{\text { berat jenis bahan bakar solar }} \\
& =\frac{21,08 \mathrm{~kg}}{0,832 \mathrm{~kg} / \mathrm{l}}=\mathbf{2 5 , 3 4 \mathrm { l }}
\end{aligned}
$$


Jadi estimasi harga rata-rata konsumsi bahan bakar spesifik mesin diesel untuk menggerakan generator set selama 1 (satu) jam adalah sebanyak 25,34 liter. Dengan melakukan perhitungan yang sama, rata-rata konsumsi bahan bakar spesifik mesin diesel untuk menggerakan generator set selama 1 (satu) jam dengan asumsi penghematan konsumsi daya listrik dari peralatan listrik yang digunakan disajikan pada tabel di bawah ini.

Penerapan manajemen energi yang baik seperti mengontrol pengkondisi udara pada ruangan-ruangan yang tidak dipergunakan, mengkondisikan mode screen saver pada PC dan laptop yang tidak dipergunakan terusmenerus, memanfaatkan penerangan alami pada siang hari serta melakukan penghematan pada semua peralatan listrik lainnya maka dapat diasumsikan konsumsi daya listrik akan berkurang sehingga beban puncak juga akan berkurang dan pada akhirnya juga menghemat biaya operasional dan konsumsi bahan bakar sistem pembangkit listrik tenaga diesel cadangan pada gedung Politeknik Muara Teweh seperti tersaji pada gambar diagram batang di bawah ini.

Tabel 5. Rata-rata Konsumsi Bahan Bakar Spesifik Mesin

Generator set selama 1 (satu) Jam Saat Beban Puncak pada Gedung Politeknik Muara Teweh

\begin{tabular}{|c|l|c|c|c|c|c|}
\hline \multirow{2}{*}{$\begin{array}{c}\text { N } \\
\text { o }\end{array}$} & \multirow{2}{*}{$\begin{array}{c}\text { Nama } \\
\text { Gedung }\end{array}$} & \multicolumn{4}{|c|}{$\begin{array}{c}\text { Asumsi Pengematan Daya Listrik } \\
\text { (kW) dari Beban Puncak }\end{array}$} \\
\cline { 3 - 7 } & $\begin{array}{c}\mathbf{1 0} \\
\text { \% }\end{array}$ & $\begin{array}{c}\mathbf{2 0} \\
\text { \% }\end{array}$ & $\begin{array}{c}\mathbf{3 0} \\
\text { \% }\end{array}$ & $\begin{array}{c}\mathbf{4 0} \\
\text { \% }\end{array}$ & $\begin{array}{c}\mathbf{5 0} \\
\text { \% }\end{array}$ \\
\hline 1. & $\begin{array}{l}\text { Lantai 1 } \\
\text { Direktorat }\end{array}$ & 14,5 & 12,9 & 11,3 & 9,7 & 8,0 \\
\hline 2. & $\begin{array}{l}\text { Lantai 2 } \\
\text { Direktorat }\end{array}$ & 51,4 & 45,7 & 40,0 & 34,3 & 28,5 \\
\hline 3. & $\begin{array}{l}\text { Lantai 1 } \\
\text { Perkuliahan }\end{array}$ & 8,2 & 7,3 & 6,4 & 5,5 & 4,5 \\
\hline 4. & $\begin{array}{l}\text { Lantai 2 } \\
\text { Perkuliahan }\end{array}$ & 10,6 & 9,4 & 8,3 & 7,1 & 5,9 \\
\hline $\begin{array}{c}\text { Total konsumsi } \\
\text { daya (kW) }\end{array}$ & 84,7 & 75,3 & 66,0 & 56,6 & 46,9 \\
\hline $\begin{array}{c}\text { Rerata konsumsi } \\
\text { bahan bakar } \\
\text { spesifik (liter) }\end{array}$ & 28,1 & 25,3 & 20,4 & 16,9 & 14,0 \\
\hline
\end{tabular}

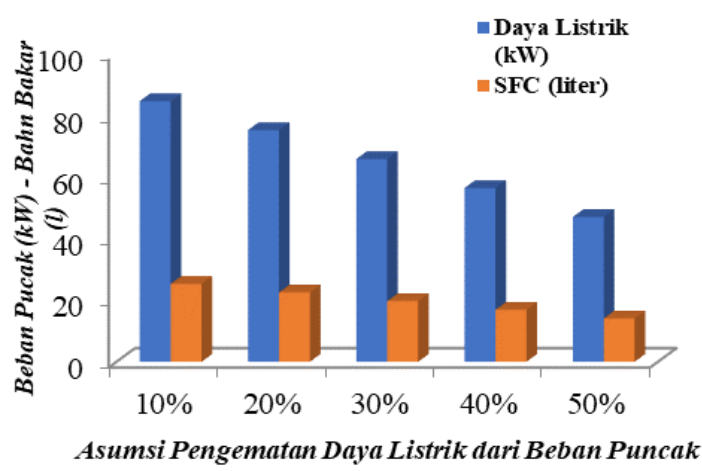

Gambar 5. Perbandingan Beban Puncak dan SFC Genset

Berdasarkan gambar diagram batang di atas, dengan asumsi penghematan $50 \%$ dari penggunaan daya listrik pada saat beban puncak dengan menerapakan manajemen energi yang baik, penghematan konsumsi bahan bakar dari pengoperasian mesin generator set mencapai 14 liter setiap jam.

\section{KESIMPULAN}

Kesimpulan-kesimpulan yang dapat disampaikan dari hasil penelitian ini antara lain adalah sebagai berikut :

1. Karakteristik beban daya listrik pada gedung Politeknik Muara Teweh terdiri dari beban daya listrik untuk penerangan, pengkondisi suhu ruangan (AC), peralatan elektronik (komputer dan laptop), peralatan laboratorium serta perlatan pendukung akademik lainnya dengan proyeksi beban puncak (pukul 8 sampai dengan pukul 14) adalah sebesar $94,168 \mathrm{~kW}$.

2. Penggerak utama generator set adalah mesin diesel bermesin turbo 6 (enam) silinder dengan sistem pendingin luar dengan kapasitas daya keluaran sebesar $128 \mathrm{~kW}$ dan efisiensi mesin 0,95 dengan kecepatan putaran sebesar $1500 \mathrm{rpm}$. Bahan bakar jenis solar dengan konsumsi bahan bakar spesifik pembebanan $100 \%$ sebesar $212 \mathrm{~g} / \mathrm{kWh}$, pembebanan $75 \%$ sebesar $208 \mathrm{~g} / \mathrm{kWh}$ dan pembebanan $50 \%$ sebesar $212 \mathrm{~g} / \mathrm{kWh}$.

3. Rata-rata konsumsi bahan bakar spesifik (BSFC) dari mesin diesel untuk menggerakan generator set yang diproyeksikan untuk memikul beban puncak selama 1 (satu) jam diestimasikan sekitar 28,16 liter dan dengan asumsi penghematan $50 \%$ pada saat beban puncak dengan menerapakan manajemen energi yang baik, penghematan konsumsi bahan bakar dari pengoperasian mesin generator set mencapai 14 liter setiap jam.

\section{REFERENSI}

[1] Sekretariat Perusahaan PT. PLN (Persero), Jakarta. Statistik Tahun 2014, Nomor Publikasi 02701150430, ISSN 0852 - 150430, April 2015.

[2] PT. PLN (Persero), Wilayah Kalimantan Selatan dan Kalimantan Tengah, Banjarbaru. Rencana Penyediaan Tenaga Listrik (RPTL) Kalimantan Selatan dan Kalimantan Tengah 2010 - 2019, September 2009.

[3] Berahim, H., Pengantar Teknik Tenaga Listrik, Teori Ringkas dan Penyelesaian Soal, Andi Offset, Yogyakarta, 1994.

[4] Bird, J., Electrical Circuit Theory and Technology, Revised Second Edition, Newnes, Elsevier Science Linacre House, Jordan Hill, Oxford OX2 8DP 200 Wheeler Rd, Burlington, MA 01803, 2003.

[5] Gonen, T., Electrical Power Distribution System Engineering, McGraw Hill, California State University, Sacremanto, 1986.

[6] Baharrudin dan Ferdi, H., Program Studi Teknik Elektro, Universitas Mercubuana, Jakarta. Perhitungan Optimasi Bahan Bakar Solar pada Pemakaian Generator Set di BTS, Jurnal Teknik Elektro, Volume 6 No. 2, ISSN 2086 - 9479, Mei 2015, halaman $61-79$.

[7] Ghiffir, Y. A., Perbandingan Unjuk Kerja Genset 4Langkah Menggunakan Bahan bakar Bensin dan LPG dengan Menambahkan Mixer Venturi, Jurusan Teknik Mesin, Fakultas Teknologi Industri, Institut Teknologi Sepuluh Nopember, Surabaya, 2010. 